\title{
Smart EcoCUVA - Tools for Food Marketing Strategy
}

Maarit Pallari

MTT Economic Research / Agrifood Research Finland (http://www.mtt.fi)

IIASA International Institute for Applied Systems Analysis (http://www.iiasa.ac.at)

\begin{abstract}
The implementation of the green productivity and marketing concept in agribusiness is a must in the future. Food production is influenced by the environment and society, and vice versa. Today a growing number of consumers are aware of the link between environmental and social well-being and fresh, pure, healthy, tasty and safe foodstuffs. Enterprises will have to consider three important aspects of value when doing business: economic, social and environmental value. The foundation of the quality research this study is concerned with is action research. Action research is a way to analyze sustainable development, the aptness of agriculture and the marketing opportunities these offer for developing ecoproducts in the SMEs.

The study seeks to answer the following questions:

- What kind of Classical Utility Value Analyses could be tool of the eco-product?

- To what extent can a customer/interest group affect the development and decision-making of ecoproducts?

- Is the method a suitable tool for analyzing ecological criterions in the marketing model?
\end{abstract}

Classical Utility Value Analysis is a formal, analytic approach for evaluating and comparing different alternatives. It is one decision making method of multi-criteria analysis. The roots of utility value analysis, which is one of the mathematical models for analytical decision making, are in the USA and Germany. The method is almost 40 years old, of the same age as the manuscript of the values tradeoff. The same historical language is being used to build up new tools, principles and theory. The so-called Smart EcoCUVA has used both methodologies (Utility value analysis and decision making analysis) when setting the goals and mathematical steps. Research results always give the best available alternative.

Making rational decisions for any complex problem requires various analyses of trade-offs (compromises) between conflicting goals (objectives, outcomes) that are used for measuring the results of applying various decisions in a wide range of application fields. A typical decision problem has an infinite number of solutions, and decision makers are interested in analyzing trade-offs between those that correspond to their preferences, which is often called a preferential structure of the decision-maker.

Smart EcoCuva analysis helps to assess different alternatives according to a variety of environmental criteria associated with enterprises and their products. The analysis methods take account of the monetary and non-monetary aspects when determining the selection of the best alternative. Smart EcoCuva is the methodological cornerstone for the creation of an innovative concept that will contribute to encouraging the efficient use of natural resources and thereby enhancing sustainability.

The Smart EcoCuva tools to be developed aim to be environmentally sound, economically viable, socially just and culturally appropriate. They are a new, science-based reaction of sustainable agriculture to global atmosphere, as well as constitute an appropriate link between people and nature. New environmentally friendly food combines healthy food with people's lifestyles.

Keywords; sustainable agriculture, product development, multi-criteria analysis, SME 


\section{Smart EcoCUVA - Tools for Food Marketing Strategy}

Maarit Pallari

MTT Economic Research / Agrifood Research Finland (http://www.mtt.fi)

IIASA International Institute for Applied Systems Analysis (http://www.iiasa.ac.at)

Our Common Future is the report made by the World Commission on Environment and Development (WCED) in 1987. The report highlights three key components to sustainable development: environmental protection, economic growth and social equity. The environment should be conserved and our resource base increased, by gradually changing the ways in which we develop and use technology. The scope of this research was the based on the European Commission's Integrated Product Policy IPP $(1998,2000,2001$ and 2001/KOM 68 final and 2003/KOM 302 final), a European Union strategy for sustainable development (2001/KOM 264 final and 2002) and Public Policy Initiatives to promote the uptake of Environmental management systems in small and medium-sized enterprises. (European Commission 2003/ KOM 26 final and SEC 58, 2003 and 2004). The Organization for Economic Cooperation and Development (OECD) encourage to used four different sustainable development elements; make wider use of markets, strengthen decision-making processes, science and technology and manage links to the global economy.

Green Marketing Strategy will be linked value-based innovation product and service. Value-based green marketing strategy and innovators assess business opportunities without being biased or constrained by where they are at a given moment. for that reason, value innovators not only have more insight into where value for buyers resides and how it is changing but also are much more likely to act on that insight. (Kim Chan \& Mauborgne 1997 and Partridge 2003).

The purpose of the research is to support small enterprises in improving their competitiveness, succeeding in the field of environmental marketing and customer oriented product development and fulfilling the principles of sustainable development. The value-based analysis (figure 1) is meant to serve as a strategic development tool for the enterprise as well as its stakeholders and it can also be included in the green marketing strategy (Charter, M. \& Polonsky, J. 1999).

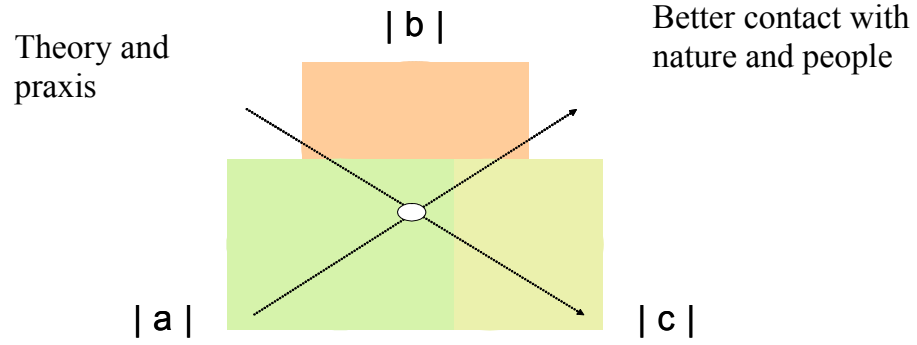

Business

innovation

New environmentally friendly product
Figure1. Goal of the value-based marketing strategy is functional integrity where added value is more than just one part of the whole. Value, $|\mathrm{x}|=\mathrm{a}$,environmental $+\mathrm{b}$,economic $+\mathrm{c}$,social \& cultural

The foundation of the quality research this study is concerned with is action research (Kuula 1999). Action research is a way to analyze sustainable development, the aptness of agriculture and the marketing opportunities these offer for developing ecoproducts in the SMEs (Churchill \& Iacobucci 2005 and Koskinen \& Alasuutari \& Peltonen \& 2005). Utility Value Analysis methods have shown efficiency and reliability (Zangemeister 1976, Bechmann 1978 etc.). They have been also used in different sectors, for example in engineering, construction, trade administration, project management, environmental management as well as in landscape planning. Principally these kinds of models are used to find solutions for decision problems where quality and other non-monetary aspects should determine the selection of the best alternative. Diller (1998) also recommended the "Standard Utility Value Analysis" in his book 
"Marketingplanung" as a useful and reliable marketing tool and Plehn (2003) recommended analysis to use sustainable development industrial products.

The study seeks to answer the following questions:

- What kind of Classical Utility Value Analyses could be tool of the eco-product?

- To what extent can a customer/interest group affect the development and decision-making of ecoproducts?

- Is the method a suitable tool for analyzing ecological criterions in the marketing model?

Marketing planning process included marketing instruments, marketing strategy marketing objectives and marketing rules. Marketing objectives must be first defined and then give answer to the questions "Where do we want to go?" and "what information we need?" Secondly comes marketing strategy and marketing policy. They are often different ways of reaching the destination. It is possible to choose the most beautiful, the shortest or fastest route to find the answer to the questions "Which way do we want to go?" and "Which qualitative and other objectives do we want to achieve?" Last the questions are "How do we want to get there?" and "What financial, human and natural recourses can we use most efficiently?" (Marketing instruments) There are different carrier opportunities by which to reach the destination. Of course, marketing planning process includes answers to the questions "What must be done by whom, when and how?" and "How will we measure success or failure?" and finally had to check and update marketing rules (OMIaRD; Schmid, O. et. al. p. 78-80, 2004 and Churchill, G. A,. \& Iacobucci, D. 2005).

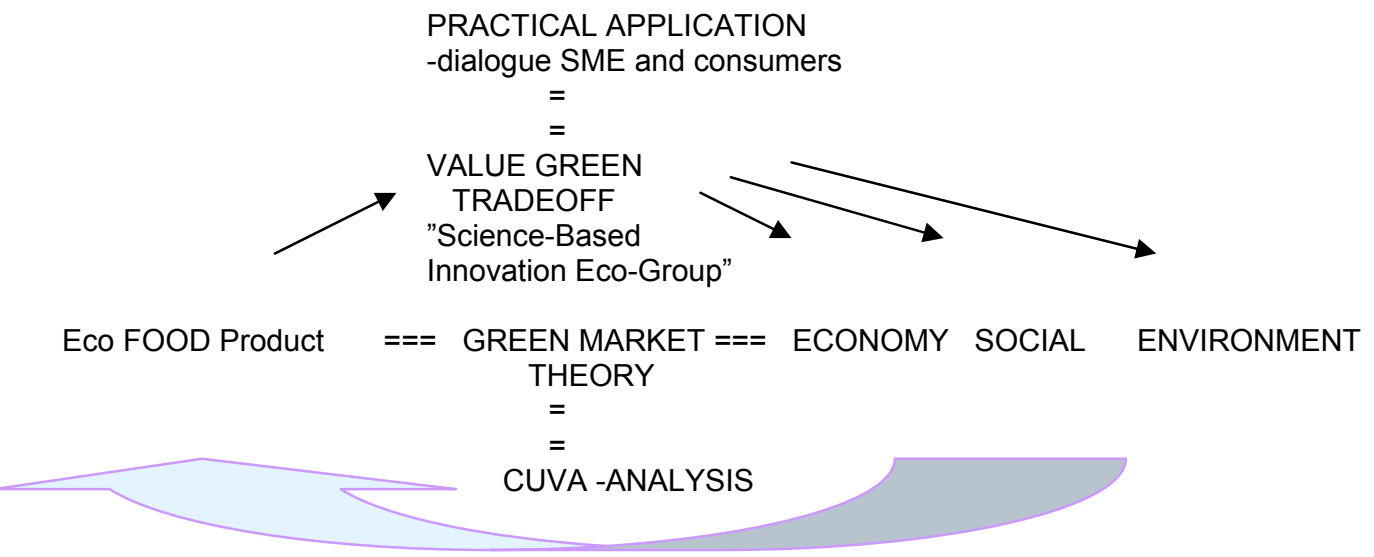

Figure2. Design data-collection methods and forms

\section{Smart ECOCUVA - process}

In the beginning development ecodesign concept for SME is SME development concept. "The small rural enterprise's development concept" is based on the enterprise's background, business activities, management, stakeholders, environmental values and the environmental database used by the entrepreneur. In this first part, the entrepreneur should examine:

- Environmental values regarding the enterprise and interaction with the environment. The entrepreneur should also recognize outstanding needs and identify specific environmental competences and skills.

- Business activities, available resources, working capacity and know-how.

Pallari, M. 2005. Smart ECOCUVA - Tools for Food Marketing Strategy. Suomen Maataloustieteellinen Päivät 2006. 
- Financial plan that includes future investments, return rates and capital needs in short and long term.

- Situation in the market through a marketing assessment. Target market, customers, competitors and authority should be identified and analysed. It is important that the entrepreneur is able to understand his/her customers' needs and wants especially in relation to green products, food quality and safety.

- Business background, purpose and goals in short- and long-term. The entrepreneur should also identify new green product ideas and evaluate them. This can be done by listening to different stakeholders, through meetings, surveys or spontaneous conversations.

The database should provide the entrepreneur with information about environmental management systems, certificates and other relevant information (i.e. the Life Cycle Assessment "LCA"). This kind of information can be seen as official guidelines for the development of green products (Seppänen et. al. 2004). They do not provide answers to all the questions, but they give an idea about what issues should be regarded when developing such products. Small rural enterprises can get this information from the Internet, books and articles. It is important to remark that the rural entrepreneur should decide what kind of information and skills are needed to develop green products.

Finally, in the development concept stage the entrepreneur defines the concept, target market, benefits, features and attributes of the green product. A competitive analysis should be undertaken to identify competitors' similar green products, their strengths and weaknesses and their marketing. After this stage the entrepreneur can begin to develop green products (Pallari 2004).

"The product development" consists of issues that are related to the product, environment-friendly values, marketing, price and evaluation. In this second part the entrepreneur involved in the product development stage should:

- Take different eco-criteria into consideration while developing a green product. The eco-criteria are linked to the enterprise's culture and ideology, product components, product life cycle, product plan and legal rules. The eco-criteria should represent a kind of guideline for developing green products and achieving an optimal food quality and safety. They should be in balance with the enterprise's development concept.

- Plan the marketing concept for the green product. Information and communication channels should be opened and targeted to all stakeholders related to the enterprise. Employees' and customers' education will form part of this stage. The entrepreneur should use this stage to reach the customers and build a trustful relationship with them.

- Determine a price for green products, which considers both the costs of the production and the added-value of the product. The product prices should become more reasonable for the customers and the producer in the future. A win-win relationship should be established between them.

- Carry out a continuous evaluation, assessment and risk analysis concerning the production process and product quality.

- Develop the green product by considering these stages and testing different prototypes. The green product development is a continuous process, which tries to adapt the enterprise's green product to the needs and wants of the customers, which at the same time change over time.

After this stage the entrepreneur can use "Smart decision goal system"; SME's goals, action motive, action restrictions of the decision. The elements of a goal system must have a important and objective description of alternative's consequences, on the other hand it must contain all relevant worth dimensions of the decision maker. Within the goals had to be clear all limits of action possibilities, so the evaluation is made on a good base. The connection among decisions is not in what will decided, but in how will be decide. The

Pallari, M. 2005. Smart ECOCUVA - Tools for Food Marketing Strategy. Suomen Maataloustieteellinen Päivät 2006. 
only way to make good decisions is using a good decision-making process. An effective decision-making process will fulfil these six criteria:

- It focuses on what's important.

- It is logical and consistent.

- It acknowledges both subjective and objective factors and blends analytical with intuitive thinking.

- It requires only as much information and analysis as is necessary to resolve a particular dilemma.

- It encourages and guides the gathering of relevant information and informed opinion.

- It is straightforward, reliable, easy to use and flexible.

A decision-making approach that addresses these criteria can be practiced on decisions major and minor is important to understand that a decision-making approach does not tell you what to decide, but how to decide. Even the most complex decision can be analyzed and resolved by considering a set of eight elements. The first five Problem, Objectives, Alternatives, Consequences, and Tradeoffs constitute the core of this approach and it is applicable to any decision. The acronym for this PrOACT serves as a remainder that the best approach to decision situations is a proactive one. The three remaining elements uncertainty, risk tolerance, and linked decisions help clarify decisions in volatile or evolving environments. The essence of the PrOACT is to divide and conquer. The eight keys will be explained as follows:

- Work on the right decision problem: The way you frame your decision at the outset can make all the difference. To choose well, you need to state your decision problems carefully, acknowledging their complexity and avoiding unwarranted assumptions and option-limiting prejudices.

- Specify your objectives: Thinking through the objectives will give direction to your decision making.

- Create imaginative alternatives: Alternatives are the different course of actions that can be chosen. The decision can be not better than the best alternative.

- Understand the consequences: It is important to see how well your decision is satisfying the objectives.

- Grapple with your tradeoffs: Objectives frequently conflict with each other; therefore it is important to find a balance. In most complex decisions, there is no one perfect alternative Different alternatives fulfil different constellations of objectives.

- Clarify your uncertainties: Uncertainty makes choosing more difficult. But effective decision making demands that you confront uncertainty, judging the likelihood of different outcomes and assessing their possible impacts.

- Think hard about your risk tolerance: When decisions involve uncertainties, the desired consequences may not be the one that actually results. A conscious awareness of willingness to accept risk will make your decision-making process smoother and more effective.

- Consider linked decisions: Many important decisions are linked by the time. The key of dealing with linked decisions is to isolate and resolve near-term issues while gathering the information needed to resolve those that will arise later.

The eight PrOACT elements provide a framework that can profoundly redirect decision making, enriching possibilities and increasing chance of finding a satisfying solution. (Hammond etc. 1999).

This PrOACT helps SME description of values and The "Classical Utility Value Analysis" steps can be described as follow:

- Build a goal system and description of values

- Identify and define the problem

- Identify the alternatives to be appraised

Pallari, M. 2005. Smart ECOCUVA - Tools for Food Marketing Strategy. Suomen Maataloustieteellinen Päivät 2006. 
- Identify the criteria for assessing the consequences of each alternative

- Determine the scale

- Weighting. Assign weights for each of the criterion to reflect their relative importance to the decision

- Combine the weights and scores for each of the criterion to reflect their relative importance to the decision.

- Calculate overall weighted scores for each alternative

Principally UVA helps to find solutions for decision problems where besides monetary aspects also quality and other non-monetary aspects determine the selection of best alternative. The "Utility Value Analysis" is a decision and assessment tool that helps to make the best decision about which product or service should be developed. With its help, it is possible to take economical, social and environmental values into consideration, when looking for the best suitable product or service. Results can be clear higher value level companies for example the Gulpener Bier ambition statement is 'Connected to nature' or Harineras Villamayor, a flour producer from northern Spain and member of the UN Global Compact, are an example of an SME combining responsible workplace and environmental practices at the local level with a global vision of Community involvement (Responsible Entrepreneurship. 2003. Tybirk et. al. 2004).

\section{Summary}

Science-Based Innovation Eco-Group is the key to successful alternatives;

Innovation Eco-Food Group consists of people who help to make the best decision. Decisions can be made by individual decision makers or groups of decision makers. The group can be the same in different parts of the processing of the analysis, but normally one group should consist of product users and one group of experts in different fields of eco-food development and business. When trying to find a decision making group to assist with a decision making problem on eco-food, most SMEs cannot find the right people or knowledge at the right time. Raiffa's idea is that we should combine theories with deep understanding of the cognitive and behavioral aspects involved in real life decision making. Only then can we touch real facts and arts in the development of sustainable agriculture (Keeney, R. L. \& Raiffa, H. 1976 and Raiffa, H. 1982). The so called eco-food values tradeoff helps to negotiate and find solutions through different kinds of expert knowledge.

Smart ECOCUVA - Tools Benefits;

- SME can find new or better way to profit on the market area.

- SME can focus better what kind of Food production SME is in the future.

- SME can use eco-efficient statistics, index, criteria what they can development companies and make better results

- SME can give more useful information consumers and consumers can make a better selection buying Food choice.

Green Marketing Strategy is a key for a open sustainable development competitive area but SME's need clear alternatives of different sustainable facts to development clear product profiles. Statistics are difficult to read and understand and if we open share SME can wish develop new innovative products and provide activity role bigger companies and consumers. Today it's possible big industrial companies. Now SME's had to go to many information desks. Multiple criteria methods are helpful but cannot solve the problem on its own. Of course, it's difficult. Principally Smart ecoCUVA helps to find solutions for decision problems where besides monetary aspects also quality and other non-monetary aspects determine the selection of best alternative.

Today the development of new eco Food products is complicated and it's difficult to share the necessary knowledge and statistical facts. But this is by no means impossible situation is crucial. We can say that

Pallari, M. 2005. Smart ECOCUVA - Tools for Food Marketing Strategy. Suomen Maataloustieteellinen Päivät 2006. 
communication issues of the future Food system (Pallari 2006). Francis, C. (et al. 2003) had found similar results: We had to sort out the complexities of recourse to use and environmental impacts that result from alternative agricultural and food processing systems. Smart is to ask relevant Food questions; how, which way, who can develop new eco Food product, interpret statistics and project / research results, apply this information to design of productive and sustainable agro ecosystems. Different alternative our Food systems offer keys and tools like as Smart ecoCUVA. Same results would describe also languages problems of the future Food economic implications and long-term impacts of alternative systems (Francis, C. et. al. 2003). At the same time we need knowledge of local process as well as global impacts. Smart choice is finding short connection links between consumer's and eco-Food developers.

\section{References}

Bechmann, A. 1978. Nutzwertanalyse, Bewertungstheorie und Planung. 1. Aufl. Bern, Stuttgart: Haupt. 361 s. ISBN 3-258-02694-7.

Charter, M. \& Polonsky, J. (edit.) Green Marketing: A Global Perspective on Greening Marketing Practice. ISBN 1874719144. p. 432 Greenleaf Publishing Limited.UK

Churchill, G. A.. \& Iacobucci, D. 2005. Marketing Research. Methodological Foundations. $9^{\text {th }}$ Edition. p. 697. ISE 0324-23693-X. Printed in United States of America.

Diller, H. 1998. Marketingplanung. 2. Aufl. München: Verlag Franz Vahlen. 402 s. ISBN 3-8006-2271-8.

European Commission. 2004. http://europa.eu.int/comm/environment/ipp/home.htm

EEC 2092/91. Articla 2. http://www.mmm.fi/el/laki/kara/luomu.html. http://europa.eu.int/eurlex/fi/consleg/pdf/1991/fi_1991R2092_do_001.pdf

Francis, C., Lieblein, G., Gliessman, S., Breland, T. A., Creamer, N., Harwood, R., Salomonsson, L.., Helenius, J., Rickerl, D., Salvador, D., Wiedenhoeft, M., Simmons, S., Allen, P., Flora. C. \& Poincelot, R. 2003. Agroecology: The Ecology of Food Systems. Journal of Sustainable Agriculture, Vol. 22/3 2003. The Haworth Press Inc.

Hammond, S. J., Keeney L. R., Raiffa, H.1999. Smart Choices. A practical guide to making better decisions. Harvard Business School Press. Boston. Massaschusetts. . ISBN 0-87584-857-5.

Keeney, R.L. \& Raiffa, H. 1976. Decisions with Multiple Objectives: Preferences and Value Tradeoffs. United States of America. ISBN 0-471-46510-0

Kim, Chan, W. \& Mauborgne, Rene'e A. 1997. Value Innovation: The Strategic Logic of High Growth. p. 189-217. Published Harward Business Review on Breakthrough Thinking.1999. ISBN 1-57851-181-X.

Koskinen, I. Alasuutari, P. Peltonen, T. 2005. Laadulliset menetelmät kauppatieteissä. s. 350. Vastapaino Tampere.

Kuula, A. Toimintatutkimus. Kenttätyötä ja muutospyrkimyksiä. s. 240. Vastapaino. Tampere.

Organic Marketing Initiatives and Rural Development (OMIaRD). Newsletter April 2004 p. 1-8. Visited: 07.08.2005. Available in Internet: $\mathrm{http}: / /$ www.irs.aber.ac.uk/omiard/newsletters pdf/April\%20\%202004\%20Newsletter.pdf and volume X, Schmid, O. et. al. p. 78-80 2004.

Pallari, M. 2004. Ekotuotteistamisen vihreä markkinointimalli - pienyritysten mahdollisuudet ja keinot. MTT:n selvityksiä 76 (2004). 91 s., 8 liitettä. ISBN 951-729-907-9 (painettu). ISBN 951-729-908-7 (verkkojulkaisu).

Pallari, M. 2006. Utility Value Analysis for Eco-Food System - Potential and opportunities for rural small enterprises. Unpublished IIASA Interim Report.

Partridge, E. 2003. In search of sustainable values. Int. J. Sustainable Development. p. 25-41. Vol. 6. No. 1. ISSN 0960-1406.

Plehn, M. 2003. Bewertung umweltgerechter Produktkonzeptionen. P. 208. Universität Hamburg. ISSN 1435-6228. ISBN 3-8300-0771-X.

Pallari, M. 2005. Smart ECOCUVA - Tools for Food Marketing Strategy. Suomen Maataloustieteellinen Päivät 2006. 
Seppänen, T., Pesonen, I., Forsman-Hugg, S., Kurppa, S., Leinonen, J., Pallari, M., Seppälä, A., Vehmasto, E., Voutilainen, P. 2004. Rural LIFE Design - Maaseutuyritysten ympäristöarvoja tuotteistamassa. MTT:n selvityksiä 82: 55 s. http://www.mtt.fi/mtts/pdf/mtts82.pdf Verkkojulkaisu päivitetty 28.12 .2004

Responsible Entrepreneurship. 2003. A collection of good practice cases among small and medium-sized enterprises across Europe:1-60. Visited: 10.08.2005. Available in Internet: http://europa.eu.int/comm/enterprise/entrepreneurship/support_measures/responsible_entrepreneurship/doc/resp_en trep_en.pdf .

Tybirk, K., Alroe, H., Frederiksen, P. N. 2004. Quality in organic farming: A conceptual analysis of considerations and criteria in a european context: 1-13.

WCED. 1987. Our common future: The World Commission on Environment and Development. Bruntland G. H. Available in Internet: http://www.provincia.fe.it/agenda21/documenti/bruntland_report.htm and http://www.dergruene-faden.de/text/text2805.html. Sustainable development and saving the world. Available in Internet: http://web.uvic.ca/ stucraw/Lethbridge/MyArticles/Brundtland.htm Visited: 03.08.2005

Zagenmeister, C. 1976. Nutzwertanalyse in der Systemtechnik. 4 Aufl. München:Wittemannsche Buchhandlung.p. 370

Pallari, M. 2005. Smart ECOCUVA - Tools for Food Marketing Strategy. Suomen Maataloustieteellinen Päivät 2006. 